ppi $201502 Z U 4645$

Esta publicación cientifica en formato digital es continuidad de la revista impresa ISSN-Versión Impresa 0798-1406 / ISSN-Versión on line 2542-3185Depósito legal pp

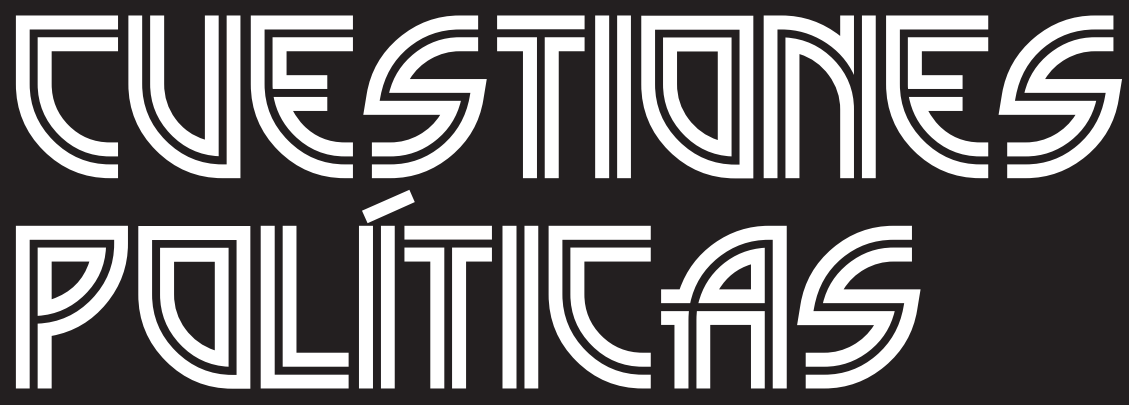

Instituto de Estudios Políticos y Derecho Público "Dr. Humberto J. La Roche' de la Facultad de Ciencias Jurídicas y Políticas de la Universidad del Zulia Maracaibo, Venezuela
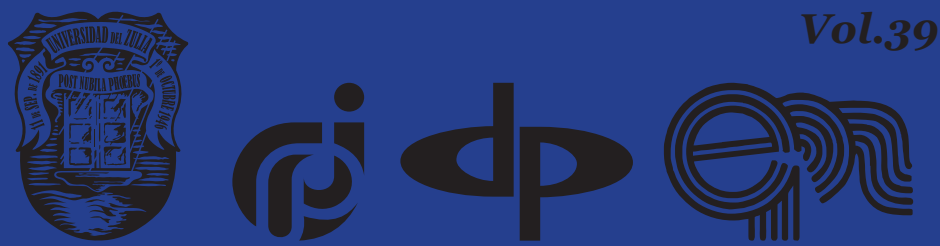


\title{
Legal Values of Russian Conservatism and Their Impact on Professional Legal Consciousness
}

\author{
DOI: https://doi.org/10.46398/cuestpol.3968.53
}

\author{
Angelina Yurievna Kuzubova * \\ Alexander Modestovich Podoksenov ** \\ Larisa L. Solovyova *** \\ Olga Andreevna Kvasova **** \\ Maria Alexandrovna Podoksenova *****
}

\section{Abstract}

Of scientific interest is the process and the result of the cognitive activity of law enforcement, which affects the functioning of the entire legal system. The problem of developing the professional legal conscience of law enforcement is revealed through the study of its value component, so the reference to the legal axiology of 19th-century Russian conservatism is a relevant scientific issue. The authors consider the opinions of the main conservative thinkers of the pre-revolutionary period: K. N. Leontiev and K. P. Pobedonostsev, the heritage of I. A. Ilyin that belongs to the first quarter of the twentieth century, etc. It is concluded that professional legal understanding must be based both on the modern legal paradigm and on the national legal tradition, mentality and established positive social practices. It is necessary to correlate values of the ethical and legal categories: justice and truth, rights and duties, dignity and honor, freedom, equality, order, etc. It can be said that the modern legal conscience of special subjects accumulates many legal values of Russian conservatism, including «justice», «order», «responsibility».

Keywords: legal values; political-legal doctrine; professional legal conscience; Russian conservatism; professional ethics of lawyers.

\footnotetext{
* Voronezh State Pedagogical University, Voronezh, Russia. ORCID ID: https://orcid.org/oooo-0oo26903-1628. Email: angelinakuzubova@mail.ru

** Bunin Yelets State University, Yelets, Russia. ORCID ID: https://orcid.org/oooo-0oo1-6405-6140. Email: podoksenov2006@rambler.ru

*** Russian State University of Justice (Central Branch of the Russian State University of Justice), Voronezh, Russia. ORCID ID: https://orcid.org/oooo-ooo1-7150-6621. Email: solo_l1974@mail.ru

****Belgorod State University, Belgorod, Russia. ORCID ID: https://orcid.org/oooo-0oo3-3217-9968. Email: olya-dvornichenko@mail.ru

***** Lomonosov Moscow State University, Moscow, Russia. ORCID ID: https://orcid.org/oooo-ooo21931-3264. Email: mariapodoksenova@gmail.com
}

Recibido el 15/07/2020 Aceptado el 12/11/2020 
Angelina Yurievna Kuzubova, Alexander Modestovich Podoksenov, Larisa L. Solovyova, Olga Andreevna Kvasova y Maria Alexandrovna Podoksenova

\section{Valores jurídicos del conservatismo ruso y su influencia en la conciencia jurídica profesional}

\section{Resumen}

De interés científico es el proceso y el resultado de la actividad cognitiva de los encargados de hacer cumplir la ley, que afecta al funcionamiento de todo el sistema jurídico. El problema del desarrollo de la conciencia jurídica profesional de los encargados de hacer cumplir la ley se revela a través del estudio de su componente de valor, por lo que la referencia a la axiología jurídica del conservadurismo ruso del siglo XIX es una cuestión científica relevante. Los autores tienen en cuenta las opiniones de los principales pensadores conservadores del período pre-revolucionario: K. N. Leontiev y K. P. Pobedonostsev, la herencia de I. A. Ilyin que pertenece al primer cuarto del siglo XX, etc. Se concluye que la comprensión jurídica profesional debe basarse tanto en el paradigma jurídico moderno como en la tradición jurídica nacional, la mentalidad y las prácticas sociales positivas establecidas. Es necesaria la correlación de valores de las categorías éticas y jurídicas: justicia y verdad, derechos y deberes, dignidad y honor, libertad, igualdad, orden, etc. Puede afirmarse que la conciencia jurídica moderna de los sujetos especiales acumula muchos valores jurídicos del conservadurismo ruso, entre ellos la «justicia», el «orden», la «responsabilidad».

Palabras clave: valores jurídicos; doctrina política-jurídica; conciencia jurídica profesional; conservadurismo ruso; ética profesional de los abogados.

\section{Introduction}

The ethical teaching of A. Schweitzer dated to the first quarter of the $20^{\text {th }}$ century stated that law had lost its moral content: "We have entered into a period in which the feeling for law is hopelessly bereft of force, of soul, and sense of moral obligation. It is a period of lawfulness. Parliaments produce with easy readiness statutes that contradict the idea of law. States deal arbitrarily with their subjects without regard to the maintenance of any feeling for law" (Schweitzer, 1992). The Russia of the 21st century experiences the uncertainty of spiritual, moral, and legal values and guidelines, which makes it important to search for ways to preserve Russian legal culture and revive Russian traditions undermined by globalization. Therefore, the correlation of moral-legal values and the system of legal regulation affects not only the sphere of theoretical research but also practical issues. This concerns complex phenomena connected with the infiltration of regulatory institutions into the inner world of a person, encouraging the formation of legal duties and moral obligations to follow legal norms. 
The perception and reproduction of legal consciousness is a complex process but is simpler than the formation of moral consciousness. One makes a moral choice while appealing to the higher regulators and being aware of personal responsibility. On the contrary, compliance with law exists in the framework of uniform provisions and legal responsibility. According to A.A. Guseinov (2002), the modern high-tech world moves "towards social systems that can function regardless of people's moral qualities and motives". How will society exist without its moral foundations? Will it be able to realize its potential, in particular, its legal system? In our opinion, law deprived of moral foundations cannot acquire genuine legitimacy based on its ability to maintain order, protect citizens and restore justice. Thus, this article aims at studying the impact of legal values common to Russian conservatism on the professional legal consciousness of law enforcers.

The development of the professional legal consciousness of law enforcement officers is analyzed through the study of its values. Thus, it is recommended to refer to the legal axiology of Russian conservatism of the 19th century. The significance of the issues considered requires both special studies and their consolidation in regulatory legal acts. The analysis of axiological aspects typical of the Russian conservative doctrine, which keeps ideas and concepts on the formation and development of Russia, is important for understanding the essential features of the political and legal status of the state.

\section{Methods}

The philosophical foundations of science comprise epistemological, ontological, logical-methodological, and axiological aspects. Being a theory of cognition, epistemology analyzes the essence of techniques, forms, and methods of cognition, as well as sets the limits of cognoscibility of objects and phenomena. The ontological section of philosophy is a teaching about general categories and objective laws co-existing with the theory of knowledge and logic. The logical-methodological section develops the relationship between concepts, reasons and judgments in the context of denying the cognitive abilities of a person, their intuition and feelings. The axiological section of philosophy considers values and their hierarchy.

The axiological approach allows combining the evaluative and goalsetting functions of culture. The latter is regarded as a comprehensive phenomenon, without opposing creativity to traditions. The values-based approach to legal thinking proceeds from the perception of law as an axiological-normative system developed in specific historical conditions within the framework of certain religious, cultural, and moral attitudes. This system is recognized and embodied in the behavior of the relevant subjects. It emphasizes the continuity of legal norms expressed not only through 
Angelina Yurievna Kuzubova, Alexander Modestovich Podoksenov, Larisa L. Solovyova, Olga Andreevna Kvasova y Maria Alexandrovna Podoksenova

814 Legal Values of Russian Conservatism and Their Impact on Professional Legal Consciousness

regulatory acts but also through values. In conformity with this approach, values are both methods and goals of cognition. If law is considered from the values-based perspective, it is possible to overcome the impersonal nature of law and avoid its excessive rationalization.

The methodology of this study is conditioned by the set of methods used by Russian conservatism with due regard to the original worldview of this scientific doctrine. The chosen methods depend on specific objects of cognition, which means that each issue involves the use of its own methods. The comparativelegal method plays an important role in Russian conservatism and consists in establishing similarities or differences among the legal phenomena under consideration. The new phenomena are compared with the phenomena already studied to reveal the essence of the first. In the context of specific historical analysis, this method allows determining and examining the trends and patterns of legal processes and phenomena.

The formal-legal method describes, generalizes, classifies, systematizes, and transfers the acquired knowledge in a certain way. Using this method, we identified principles, norms and provisions reflecting legal values of Russian conservatism of different historical periods. The study of the abovementioned problems involved the use of various methods, both general (analysis, synthesis, induction, deduction, abstraction, systemic analysis) and special scientific methods (historical, comparative-legal, etc.).

\section{Results and Discussion}

The legal status of society is predetermined by many factors, including the professional understanding of law by special subjects (law enforcement officers). Such legal thinking is a process and result of the cognitive activity of law enforcement officers that affects the functioning of the entire legal system. No appeal to legal values and their perception within "the pure theory of law" deprives legal actions of any meaning. Utilized, pragmatic and formalized law cannot improve a person, as well as provide social harmony and stability. The need to replicate form and content through semantic components is an activity of lawyers. Within such an understanding, law can fulfill its high mission of achieving justice and not turning into an expired form.

Being at the center of legal regulation, lawyers contribute to the creation of laws and their implementation; therefore, they bear much social responsibility. The nature of professional legal activity allows lawyers to be regarded as creators of legal culture. To a large extent, the level of law and order in society depends on lawyers involved in law-making, law enforcement, law protection and other activities. 
The professional legal consciousness of lawyers is a special form in the system of legal views, values and skills conditioned by an appropriate academic degree and practical experience. Specific features of the professional legal consciousness of lawyers are as follows: in-depth theoretical and practical knowledge in certain areas of law; perception of the current legal system in its integration; consistency of legal knowledge, values, and commitments; understanding the essence of legal effects, etc. (Baranov, 2006). At the same time, the professional legal consciousness of lawyers is heterogeneous, which is due to the diversity of their competences and the specifics of their legal activity.

A component of the lawyer's status is the professional axiosphere that embodies the values and meanings of this profession, its norms, rules, traditions, etc. This occupation implies not only the possession of special knowledge, skills and competences confirmed by appropriate diplomas, certificates, and other documents but also values-based orientations towards serving public goals. Professional affiliation with the legal profession presupposes a positive assessment of the current law and a wellformed desire to embody legal values in official and private practice. The knowledge of laws does not imply their correct assessment. On the contrary, even an adequate assessment can undermine the regulatory potential of law due to the prevalence of negative legal attitudes.

The professional ethics of lawyers is characterized by a high level of integration between legal and moral norms that govern their activities. Law enforcement officers (in particular, judges, prosecutors, and investigators) have a special status and fulfill their mission relying not only on law, but also on their conscience and moral convictions. Special functions of the legal community necessitate the introduction of increased requirements for the moral status of its members, which was embodied in the development of ethical norms. For example, there are the Code of Professional Ethics of Lawyers in the Russian Federation (Council of the Federal Chamber of Lawyers of the Russian Federation, 2003), the Code of Professional Ethics for Procuracy Officers in the Russian Federation (Prosecutor's Office of the Russian Federation, 2010), the Code of Judicial Ethics in the Russian Federation (All-Russian Congress of Judges, 2012), the Code of Professional Ethics for Notaries in the Russian Federation (Ministry of Justice of the Russian Federation, 2016), etc.

According to V.V. Sorokin (2010), "every person has not only a justified legal but also a moral obligation to obey the existing norms since law prescribes the same external behavior as the one considered moral and just by the still small voice". Such categories as "conscience", "justice" and "duty" determine the substantial component of law. Defining legal consciousness as an instinctive sense of law, the will to spirit, justice and goodness, I.A. Ilyin believed that it is expressed through conscience and religious feelings: 
Angelina Yurievna Kuzubova, Alexander Modestovich Podoksenov, Larisa L. Solovyova, Olga Andreevna Kvasova y Maria Alexandrovna Podoksenova

"Indeed, legal consciousness can be considered outside the framework of religion and conscience, like one's will be devoid of heaven and earth. It will be $\langle\ldots\rangle$ a shallow form deprived of the gift of love and contemplation" (Ilyin, 1993: 236).

As a category of ethics, conscience reflects the ability to perform selfevaluation and correlate one's behavior with the requirements of morality, which helps a person to choose a suitable behavioral pattern. Conscience is independent of society and state, but it is important for these institutions since it creates ideological preferences. The modern legal theorist R.S. Bainiyazov defined legal conscience as "an intuitive understanding and striving for a just life and moral law" (Polyakov and Timoshina, 2005). The Orthodox perception of conscience focuses on the fact that it is an innate moral feeling that unites a person with the Creator and distinguishes between good and evil outside the framework of rational comprehension. This is an internal "judge" who approves thoughts, intentions, and actions.

The legal dimension of conscience lies in its potential as a spiritual and moral law to ensure the correct assessment, respect, and observance of legal rights without external means of coercion. Conscience coexists with the feelings of duty, responsibility, and shame. The latter is expressed in self-reproach and awareness of spiritual unworthiness when some immoral act is suddenly exposed. Duty should be interpreted as moral readiness to perform certain actions and be responsible for them. Responsibility reflects the person's perception of moral and legal values and the ability to act, realizing the consequences of such actions.

It is hard to overestimate the role of conscience in the legal regulation of social relations. This moral feeling largely ensures legitimate behavior. The development of conscience creates natural respect for law without any coercive measures. On the contrary, the lack of conscience encourages a person to commit immoral and illegal acts and violate the established social order.

The well-developed system of legal values is a required attribute of any law enforcement officer. However, the judge's values play a special role. By virtue of its social mission, justice should comply with humanistic traditions expressed in values-based attitudes towards a person. The significance of the judicial system cannot be neglected since it aims at restoring justice, maintaining order, resolving conflicts, protecting rights, and mediating different types of social relations. I.Ya. Foinitskii described the role of justice in the following way: "Among state responsibilities, one of the most important is the obligation to administer justice. This function conditions the formation of the judiciary as a branch of state power and complements the other branches of government (legislative and executive)" (Foinitskii, 1996). Modern legal science considers justice as a specific type of state activity or judiciary function aimed at analyzing and resolving social 
conflicts associated with the actual or alleged violation of laws (Rzhevskii and Chepurnova, 1998).

Furthermore, justice is inherent in fairness and these categories are often identified. Fairness is manifested in the adequacy and compliance of the applicable laws with moral norms while assessing some act or attitude subject to judicial proceedings. In the context of legal proceedings, fairness has many aspects. First, it is an imperative that makes a person act in conformity with objective truth, law and their own conscience, relying on the facts established in a particular case. Fairness implies compliance with the concept of due order, equality of all society members, application of just laws, independent and impartial courts, proportionality of action and retribution, etc. Judicial decisions should meet the criteria of fairness. In the context of legal proceedings, the procedure is to establish the truth, ensure the equality of parties and clarify all circumstances.

The founder of the Russian judicial ethics A.F. Koni (2011) believed that judges should exert all the powers of their mind and conscience to find the truth in a certain case, while judicial verdicts should be based not only on logical inevitability but also on moral obligations. The Russian lawyer tried to reveal the functioning of the judge's inner convictions and determine moral components of the administration of justice at the theoretical level. According to A.F. Koni, the application of any law regardless of a particular situation is unworthy of a judge. Indeed, true justice lies in reasonable humanity. The special legal status of a judge presupposes certain professional, legal, psychological, moral, and ethical qualities. Therefore, it is a priority task to develop the legal culture and moral consciousness of the judiciary. This goal can be achieved through strengthening and improving the Russian judicial system.

Modern procedural and material laws legitimized such personal and moral categories as "conscience", "dignity" and "inner conviction", which emphasizes subjective and creative principles of justice. For example, the Law of the Russian Federation "On the Status of Judges in the Russian Federation" contains the following oath of a judge: "I solemnly swear to perform my duties honestly and conscientiously, to administer justice obeying only the law, to be objective and fair, as the duty of a judge and my conscience require" (Russian Federation. Federal Law, 1992). Thus, legal proceedings cannot be assessed with due regard to the judge's knowledge of positive law. Only the unity of normative and values-based systems guarantees the professionalism of the servants of Themis.

Clause 1 of Article 17 of the Criminal Procedure Code of the Russian Federation reads, "The judge, the jurors, as well as the prosecutor, the investigator and the inquirer, shall assess the proof in accordance with their inner conviction and shall rely in doing this on the law and on their conscience" (The State Duma of the Russian Federation, 2001). An inner 
Angelina Yurievna Kuzubova, Alexander Modestovich Podoksenov, Larisa L. Solovyova, Olga Andreevna Kvasova y Maria Alexandrovna Podoksenova

conviction is a complex category defined as a subjective sense of confidence and consideration of the truth, which helps judges build up an opinion regarding the rightness of the party to criminal proceedings and their guilt or innocence. Inner convictions form during an objective assessment of a particular case from the standpoint of law and with due regard to moral responsibility in relation to the parties of specific legal relations and society as a whole.

While administering justice, it is necessary to consider such a legal value of Russian conservatism of the $19^{\text {th }}$ century as a legal obligation that implies the fusion of a "moral duty" and a "legal obligation". The Russian specific laws and acts issued by the judicial community emphasize the convergence of professional activity and moral duty. The Code of Judicial Ethics introduced rules of conduct that are binding on every judge and based on high moral and ethical requirements (All-Russian Congress of Judges, 2012). The act adopted by the judicial community establishes increased moral and ethical requirements for judges due to their status. In particular, "the judge shall be guided by generally accepted standards of morality, value the honor, avoid everything that could belittle authority of judicial authority and cause damage to the reputation of the judge" (AllRussian Congress of Judges, 2012).

The issue of freedom (in particular, the freedom of choice) is no less acute in the context of being responsible and understanding the consequences of an act of justice. Being connected with moral imperatives, freedom and independence ensure the fair and impartial activity of judges. The category of "judicial discretion" should eliminate ambiguities and legal limitations by specifying the disputed law. D.M. Chechot (1973) defined judicial discretion as the freedom of a judge to make an appropriate decision. D.V. Boiko (2011) explained discretion by the objective inability to regulate all the variety of legal relations by the general norm, evaluative concepts, dispositive and peremptory norms of law, containing specific or alternative sanctions, open legal lists, legal gaps and conflicts of law. Judicial discretion allows critically considering the rules of law, assessing and analyzing them by referring to legal ideals and principles. The freedom of judicial discretion limits the independent will of judges, within which verdicts are delivered. The moral and legal boundaries of judicial discretion are defined by the categories of justice, honesty, and rationality.

The conservative thinker of the 19th century K.N. Leontev considered internal contradictions of the institute of justice. In his opinion, it is not able to find the highest truth and restore the highest justice. According to the philosopher, "the Russian proverb says where there is a court, there is a lie... The proverb does not mean that all courts are unjust. However, all human institutes have a tendency towards untruth and therefore some legal proceedings are unfair in nature... After all, the Russian people (and 
any people who have not been bewildered by democratic ideas yet) do not believe in the truth on earth..." (Leontev, 2003). Thus, K.N. Leontev emphasized that any judicial act is based on the judge's interpretation of law, moral sense of conscience and inner conviction, which does not exclude the possibility of a failure or unfair decision.

K.P. Pobedonostsev criticized judicial institutions in the following manner: "We have a machine for creating artificial truth but the truth itself cannot be seen in the solemn vanity of machine production. It is overlaid by the noise of the wheels turning inside this huge mechanism. People look for moral strength, alas, almost all the potential of this machine is wasted on the friction of the wheels making continuous motion. Almost all the moral efforts are spent on lubricating these wheels and their conductor tracks. Courts hear cases in all their priestly dignity. Like the ancient Augurs, they listen until their attention grows blunt... However, the main victim of this torture is the unfortunate truth that should make its way to the promised paradise along the narrow bridge of Mohammed. Woe betide those who rely on their own powers along the way" (Pobedonostsev, 1996). The philosopher highlighted the need to overcome the formal nature of legal proceedings and acknowledge the priority of law and conscience in establishing the truth and ensuring justice.

The shortcomings of the current judicial system can be overcome if courts are authorized to creatively apply laws, confidence in the judiciary is increased and transparency in judicial activities and other measures are ensured. The credibility of courts is built through the compliance of its activities with justice, legality, and the adopted complex of professional ethics. Adherence to ethical norms and professional rules during a court session, as well as the moral position of a judge, reflected in a verdict, serve as criteria for assessing the judge's status by public opinion, which influences the authority of courts. The Russian state needs not only to improve the existing legal framework but also to increase the legal culture of lawyers because their professional legal consciousness is somehow deformed. Legal thinking should be enriched with the achievements of legal science, intellectual traditions of the Russian politics and jurisprudence, new approaches that can fit into the existing legal framework.

The judge's socialization presupposes the evolution of their values through the interaction of personality traits and the external professional environment. President of the Constitutional Court V.D. Zorkin did not support the opposition of an individual and state. He stated, "For this, we do not need to change the core of our culture, we should correlate the spirit of our people and the content of law, traditions and innovations" (Zorkin, 2013). It is necessary to form the professional legal consciousness of judges based on the moral values of honor, dignity, the special duty of the servants of Themis, etc. Moreover, morality and ethics should be protected by justice, 
Angelina Yurievna Kuzubova, Alexander Modestovich Podoksenov, Larisa L. Solovyova, Olga Andreevna Kvasova y Maria Alexandrovna Podoksenova

otherwise, they will destabilize the system of legal values. Unfortunately, the current legislation does not ensure the true independence of judges from other branches of the state power and the higher authorities within the judicial system. As a result, judges are turned de facto into ordinary officials, which does not correspond to the nature of justice and its social mission.

The unity of values-based orientations is significant for classifying professional groups of lawyers. Legal values and ideals are the main components of the lawyer's socialization in the structure of professional legal consciousness. Therefore, any failures in the axiosphere trigger the mechanism of destruction.

\section{Conclusion}

The significance of the study results is predetermined by the following facts. The importance of judicial decisions imposes requirements not only on their quality and legality but also strengthens public demand for their humanity and justice. It is impossible without the axiological correlation of such ethical and legal categories as justice and truth, rights and duties, dignity and honor, freedom, equality, order, etc. One more development direction is the need to improve legal educational strategies and overcome technocratic that falsely represent law as orders and directives issued by authorities.

Unlike other public authorities, courts have the legislatively enshrined ability to conduct their activities based on the categories of "conscience", "honor", "dignity", "honesty", "justice", "good faith" and "duty". Their high status is due to the fact that they are the final instance and have powers to supplement and enrich the existing law with new norms of morality and ethics to obtain public and state benefits.

Legal traditions of Russian conservatism reflect the priority of mercy and philanthropy over legality (Kuzubova, 2020). The conservatism of modern legal consciousness manifests itself in the fact that the changes caused by drastic judicial reforms have little affected the foundations of professional legal thinking. At the same time, professional legal thinking should proceed from modern legal paradigms, the Russian legal traditions, mindset and established positive social practices. Trust in the judicial system is a prerequisite for its effective functioning. This trust is built over independent, fair, and humane justice, capable of harmoniously combining the requirements of law and the human spirit. Judges should not forget that a person who has an inalienable right to dignity falls in the sphere of their professional responsibility. 
The professional understanding of law by special subjects (law enforcement officers) largely affects the legal status of society. Being a process and result of the cognitive activity of law enforcement officers, legal thinking embodies the values and meanings of this profession, its norms, rules, traditions, etc. The modern legal consciousness of special subjects accumulates many legal values of Russian conservatism, including justice, order, and responsibility. Judges also focus on the improvement of moral qualities in the context of professional development. The effective functioning of the judicial system is conditioned by trust in this institute, which is possible only under the administration of truly independent, fair, and humane justice, capable of converging the legal prescriptions and human needs.

\section{Bibliographic References}

ALL-RUSSIAN CONGRESS OF JUDGES. 2012. Kodeks sudeiskoi etiki ot 19 dekabrya 2012 g. (utv. VIII Vserossiiskim sezdom sudei 19 dekabrya 2012 g.) [The Code of Judicial Ethics of December 19, 2012 (adopted by the $7^{\text {th }}$ All-Russian congress of judges on December 19, 2012)]. Rossiyskoye Pravosudiye, No. 1. Vol. 91. (in Russian).

BARANOV, Pavel Petrovich. 2006. Aktualnye problemy teorii pravosoznaniya i pravovogo myshleniya [The relevant issues of the theory of legal consciousness and legal thinking]. Rostov-on-Don: Donskoi izd. dom. (in Russian).

BOIKO, Dmitrii Valentinovich. 2011. Zakonnost i usmotrenie v pravoprimenitelnoi deyatelnosti: voprosy teorii [Legitimacy and discretion in law enforcement: theoretical issues]: an extended abstract of thesis for a Candidate Degree in Law Sciences. Volgograg State University. Volgograd, Russia.

CHECHOT, D.M. 1973. Administrativnaya yustitsiya (problemy primeneniya) [Administrative justice (application-related issues)]. Leningrad: Izd-vo Leningr. un-ta. (in Russian).

COUNCIL OF THE FEDERAL CHAMBER OF LAWYERS OF THE RUSSIAN FEDERATION. 2003. Kodeks professionalnoi etiki advokata [The Code of Professional Ethics of Lawyers]. Rossiiskaia Gazeta [Ros. Gaz.], No. 222. (in Russian).

FOINITSKII, I.Ya. 1996. Kurs ugolovnogo sudoproizvodstva [The course of criminal proceedings]. Vol. 1. Alfa. Saint Petersburg, Russia. (in Russian). 
Angelina Yurievna Kuzubova, Alexander Modestovich Podoksenov, Larisa L. Solovyova, Olga Andreevna Kvasova y Maria Alexandrovna Podoksenova

822

Legal Values of Russian Conservatism and Their Impact on Professional Legal Consciousness

GUSEINOV, A.A. 2002. Filosofiya. Moral. Politika (sbornik statei za 1997-2001 gg.) [Philosophy. Morality. Politics (the collection of articles 1997-2001)]. Akademkniga. Moscow, Russia. (in Russian).

ILYIN, I.A. 1993. O sushchnosti pravosoznaniya [The essence of legal consciousness]. Rarog. Moscow, Russia. (in Russian).

KONI, A.F. 2011. Nravstvennye nachala v ugolovnom protsesse (Obshchie cherty sudebnoi etiki) [Moral foundations of criminal proceedings (general features of judicial ethics)]. Yurisprudentsiya. No. 1, pp. 69-94. (in Russian).

KUZUBOVA, Angelina Yurievna. 2020. Pravovye tsennosti russkogo konservatizma XIX veka [Legal values of Russian conservatism of the 19th century]: monograph. Yurlitinform. Moscow, Russia. (in Russian).

LEONTEV, Konstantin Nikolaevich. 2003. Chem i kak liberalizm nash vreden [Why our liberalism is bad]. In: Khram i tserkov by K.N. Leontev (pp. 531-556). Izd-vo AST. Moscow, Russia. (in Russian).

MINISTRY OF JUSTICE OF THE RUSSIAN FEDERATION. 2016. Kodeks professionalnoi etiki notariusov $\mathrm{v}$ Rossiiskoi Federatsii (red. ot 23.04.2019) [The Code of Professional Ethics for Notaries in the Russian Federation (as amended on April 23, 2019)]. Available online. In: https:// minjust.gov.ru/ru/documents/8028/. Consultation date: 15/06/2019. (in Russian).

POBEDONOSTSEV KONSTANTIN, Petrovich. 1996. Bolezni nashego vremeni [Modern "diseases"]. In: D.K. Burlaka (Ed.), K.P. Pobedonostsev: pro et contra (pp. 137-165). RKhGI. Saint Petersburg, Russia. (in Russian).

POLYAKOV, A.V; TIMOSHINA, E.V. 2005. Obshchaya teoriya prava [General theory of law]: student's textbook. Izdatelskii Dom S.-Peterb. gos. un-ta. Saint Petersburg, Russia. (in Russian).

PROSECUTOR'S OFFICE OF THE RUSSIAN FEDERATION. 2010. Prikaz Genprokuratury Rossii “Ob utverzhdenii i vvedenii v deistvie Kodeksa etiki prokurorskogo rabotnika Rossiiskoi Federatsii i Kontseptsii vospitatelnoi raboty v sisteme prokuratury Rossiiskoi Federatsii" ot 17.03.2010 N 114 (red. ot 13.04.2018) [Order of the Prosecutor's Office of the Russian Federation "On adopting and enforcing the Code of Professional Ethics for Procuracy Officers in the Russian Federation and the Concept of educational work with procuracy in the Russian Federation” No. 114 of March 17, 2010 (as amended on April 13, 2018)]. Zakonnost' 2010 No. 6 (908). (in Russian). 
RUSSIAN FEDERATION. FEDERAL LAW. 1992. Zakon RF “O statuse sudei v Rossiiskoi Federatsii” ot 26.06.1992 N 3132-1 (red. ot 25.10.2019) [Law of the Russian Federation "On the status of judges in the Russian Federation" of June 26, 1992 No. 3232-1 (as amended on October 25, 2019)]. Rossiiskaia Gazeta [Ros. Gaz.] 29.07.1992 No. 170. (in Russian).

RZHEVSKII, V.A; CHEPURNOVA, N.M. 1998. Sudebnaya vlast v Rossiiskoi Federatsii: konstitutsionnye osnovy organizatsii deyatelnosti [Judicial power in the Russian Federation: the constitutional foundations of activity arrangement]. Yurist. Moscow, Russia. (in Russian).

SCHWEITZER, Albert. 1992. Blagogovenie pered zhiznyu [Reverence for life]. Progress. Moscow, Russia. (in Russian).

SOROKIN, Vitaly Viktorovich. 2010. Sovest v mekhanizme pravovogo regulirovaniya: voprosy teorii [Conscience in the mechanism of legal regulation: theoretical issues]. Rossiiskaya yustitsiya. No. 1, pp. 62-66.

THE STATE DUMA OF THE RUSSIAN FEDERATION. 2001. Ugolovnoprotsessualnyi kodeks Rossiiskoi Federatsii ot 18 dekabrya $2001 \mathrm{~g}$. No. 174-FZ (red. ot 27.12.2019) [Criminal Procedure Code of the Russian Federation No. 174-FZ of December 18, 2001 (as amended on December 27, 2019)]. Rossiiskaia Gazeta [Ros. Gaz.] 22.12.2001 No. 249. (in Russian).

ZORKIN, Valerii Dmitrievich. 2013. Pravo v usloviyakh globalnykh peremen [Law in the modern ever-changing conditions]: monograph. NORMA. Moscow, Russia. (in Russian). 

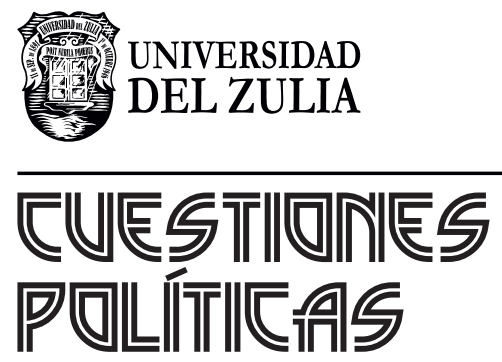

Vol.39 No 68

Esta revista fue editada en formato digital y publicada en enero de 2021, por el Fondo Editorial Serbiluz, Universidad del Zulia. Maracaibo-Venezuela 